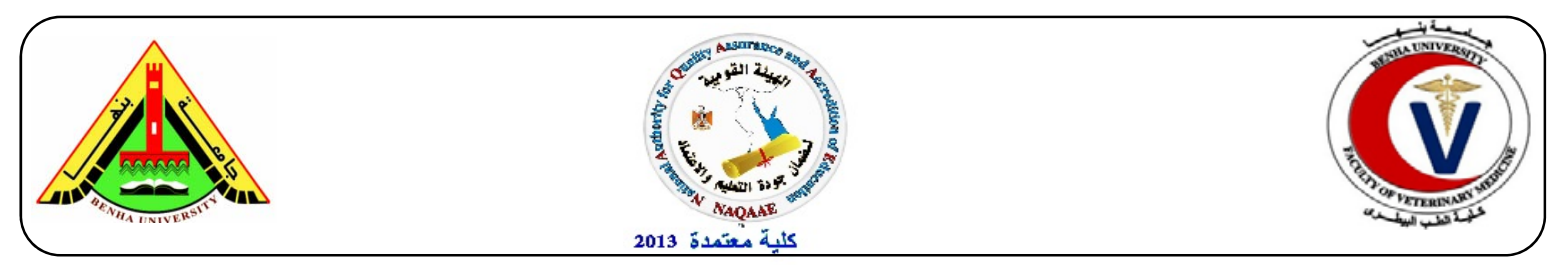

\title{
Detection of some foodborne pathogens in meat products by Polymerase Chain Reaction
}

\author{
George, A. Armany ${ }^{1}$, Hemmat, M. Ibrahim ${ }^{2}$, Reham, A. Amin ${ }^{2}$, Hanaa, A. Ahmed ${ }^{1}$ \\ ${ }^{1}$ Genome Research Unit., Animal Health Research Institute, Dokki. ${ }^{2}$ Food hygiene Dept., Faculty of \\ Veterinary Medicine, Benha University.
}

\begin{abstract}
A B S T R A C T
A total of 100 random samples of meat products including raw minced meat, raw sausage, luncheon and basterma ( 25 samples of each) were collected from different markets in Cairo and Giza governorates to be examined bacteriologically for detection of Staphylococcus aureus, Listeria monocytogenes and Escherichia coli. These samples were examined for isolation of such pathogens by conventional bacteriological methods and by polymerase chain reaction (PCR). Concerning S.aureus bacteriological results revealed the prevalence in minced meat, Sausage, luncheon and basterma was $(24 \%, 24 \%, 20 \%$, $4 \%)$ respectively. While $L$. monocytogenes revealed the prevalence in minced meat, sausage, luncheon and basterma was $(4 \%, 0 \%, 0 \%, 0 \%)$ respectively and $E$. coli revealed the prevalence in minced meat, sausage, luncheon and basterma was $(20 \%, 20 \%, 24 \%, 20 \%)$ respectively. The results cleared that PCR is an ideal method for identification of foodborne pathogens, as it was effective, less labor, more sensitive, reduces effort and time after using gradient PCR in validation of each microbe.
\end{abstract}

Keywords: foodborne pathogens, optimization, polymerase chain reaction (PCR), bacteriological isolation, Meat products.

(http://www.bvmj.bu.edu.eg) $\quad$ (BVMJ-30(1): 323-330, 2016)

\section{INTRODUCTION}

$\mathrm{F}$ ood poisoning is an illness caused by eating food that has been contaminated. Foodborne pathogens which have been recognized as the most common sources causing food poisoning worldwide and in severe cases cause death. Meat and meat products are highly perishable and can spoil easily and soon become unfit to eat and possibly dangerous to health through microbial growth, chemical changes and breakdown by endogenous enzymes (Judge et al., 1990).

Microbiological assessment is important to determine the safety and quality of food. In the past detection and identification of microorganisms have relied mainly on cultural techniques. These methods are the most reliable and accurate in the detection of foodborne pathogens. However, they are labour intensive, have long processing times and are costly. Major disadvantage to this method is that it can take 2- 3 days for any results to show up and up to 7-10 days for confirmation (Jasson et al., 2010). Polymerase chain reaction (PCR) is a powerful technique that has revolutionized molecular biology research and has application in the diagnosis of microbial infections and genetic diseases, as well as in detection of pathogens in food samples.

PCR is an advantage against the culturing methods as you can use numerous amounts of selective DNA in one PCR reaction. Recent reports have shown that PCR greatly improves specificity and sensitivity for the detection of pathogens (Huang et al., 2009).

\section{MATERIAL AND METHODS}




\subsection{Collection of samples}

Actually, 100 samples of raw meat and cooked meat (Minced meat, Sausage, Luncheon and Basterma) were collected from different markets in Cairo and Giza governorates. Samples were submitted to the lab in Animal Health Research Institute for bacteriological examination in sterile containers in a Stomacher bag.

\subsection{Sample preparation}

Actually, 25 grams of each samples were taken under aseptic condition into sterile blender jar to which $(225 \mathrm{ml})$ peptone water $(0.1 \%)$ was added, then the blender was operated to give $3000 \mathrm{rpm}$ for not more than $2.5 \mathrm{~m}$ to get a dilution of $10^{-1}$, after that $(1 \mathrm{ml})$ from the original solution was transferred into separate tube containing ( 9 $\mathrm{ml}$ ) peptone water from which (10) fold serial dilution (ICMSF, 1978).

\subsection{Bacteriological isolation}

According to Koneman et al (1996) and Quinnet al (2002), the samples were cultured for isolation of $S$. aureus onto peptone water for 24 hours at $37^{\circ} \mathrm{C}$ and then a loopful was taken and cultured onto Nutrient agar, 5\% sheep blood agar, mannitol salt agar and then onto Baird parker medium. All inoculated plates were incubated at $37^{\circ} \mathrm{C}$ for $24-48$ hours then colonies were identified. The colonies characterized by circular, smooth, convex, moist, 2-3 $\mathrm{mm}$ in diameter, gray to jetblack, frequently with light-colored (offwhite) margin, surrounded by opaque zone and frequently with an outer clear zone. All suspected colonies are tested and confirmed biochemically. According toISO 11290, the samples were cultured for isolation of $L$. monocytogenes onto peptone water for 24 hours at $37^{\circ} \mathrm{C}$ and the initial suspension prepared and incubated at $30{ }^{\circ} \mathrm{C}$ for 24 hours \pm 2 hours. A black coloration was developed during the incubation. After incubation of the initial suspension (primary enrichment) for 24 hours \pm 2 hours, $0.1 \mathrm{ml}$ of the culture obtained was transferred to a tube containing $10 \mathrm{ml}$ of secondary enrichment medium (Full Fraser broth), then incubated at $35^{\circ} \mathrm{C}$ or $37^{\circ} \mathrm{C}$ for 48 hours \pm 2 hours. From the primary enrichment culture incubated for 24 hours \pm 3 hours at $30{ }^{\circ} \mathrm{C}$, a portion of the culture was inoculated on the surface of the selective plating medium OXFORD. The seeded plates were incubated to obtain well separated colonies. Colonies showing morphological characters as dew drop-like, black with brown hallow, or dark brown colonies 1-2 mm in diameter. All suspected colonies are tested and confirmed biochemically.

According to Quinn et al (2002) samples were cultured for isolation of E. coli and inoculated separately into buffer peptone water were incubated at $37^{\circ} \mathrm{C}$ for 18 hours \pm 2 hours under aerobic condition. A loopful from the broth of each sample was streaked onto MacConkey's agar and Eosin Methylene Blue agar. The inoculated plates were incubated at $37^{\circ} \mathrm{C}$ for 24 hours. Suspected E. coli colonies were purified and kept for further identification. Where the colonies appear red on MacConkey's agar and appear as green metallic sheen EMB agar. All suspected colonies are tested and confirmed biochemically.

\subsection{Optimization of the Polymerase Chain Reaction (PCR)}

DNA extraction and purification direct from the meat products samples by Thermo Scientific Genomic DNA extraction kit used to obtain purified DNA.

Table (4) show the Oligoneucleotide primers which were designated according to Integrated DNA technology and were used for amplification, the nuclease (nuc) gene of $S$. aureus, hemolysin (hlyA) gene is essential for virulence of L.monocytogenes and universal stress protein (uspA) gene which encodes for a highly conserved universal stress protein present in all $E$. coli. The primers were received in lyophilized form and resuspended in sterilized water to reach a final concentration of $100 \mathrm{pmol} / \mu \mathrm{l}$. These 
primers suspected to amplify specific segment of 270, 456 and $884 \mathrm{bp}$. The mix used in validation of PCR on detection of foodborne pathogens according to AmpliTaq Gold 360 mastermix (Applied Biosystems) where the reaction is 6.25 $\mu$ lAmpliTaq Gold 360 mastermix (2x), $0.75 \mu 1$ PCR grade water, $1.5 \mu$ lforward primer, $1.5 \mu 1$ reverse primer, $2.5 \mu 1$ template DNAto reach a final volume of $12.5 \mu \mathrm{l}$ in the reaction. According to the methods of Henegariu et al (1997), amplifications conditions for thermocycling were $95^{\circ} \mathrm{C}$ for $5 \mathrm{~min}$ for primary denaturation and followed by 40 cycles of heat denaturation at $95^{\circ} \mathrm{C}$ for $15 \mathrm{sec}$, primer annealing at $\left(56^{\circ} \mathrm{C}-63{ }^{\circ} \mathrm{C}\right)$ for $45 \mathrm{~s}$ and DNA extension at $72^{\circ} \mathrm{C}$ for $1 \mathrm{~min}$, this was followed by final extension at $72^{\circ} \mathrm{C}$ for $10 \mathrm{~min}$. After PCR reaction, $5 \mu \mathrm{l}$ of the PCR product was resolved on $1.5 \%$ agarose gel. The gels were stained with Ethidium bromide $(0.2 \mu \mathrm{g} / \mathrm{ml})$ and photographed under UV transillumination in gel documentation system (BioRad).

\section{RESULTS}

\subsection{Results of Bacteriological isolation}

Table (1) shows the results of isolation of S.aureus revealed the prevalence in minced meat, sausage, luncheon and basterma was $(24 \%, 24 \%, 20 \%, 4 \%)$ respectively.

Table (1): Number and percentage of S. aureus of positive samples from meat products.

\begin{tabular}{cccc}
\hline $\begin{array}{c}\text { Types of } \\
\text { samples }\end{array}$ & $\begin{array}{c}\text { No. of } \\
\text { examined } \\
\text { samples }\end{array}$ & $\begin{array}{c}\text { Bacteriological } \\
\text { finding } \\
\text { No. of } \\
\text { positive } \\
\text { samples }\end{array}$ & $\%$ \\
\hline Minced meat & 25 & 6 & $24 \%$ \\
Sausage & 25 & 6 & $24 \%$ \\
Luncheon & 25 & 5 & $20 \%$ \\
Basterma & 25 & 1 & $4 \%$ \\
Total & 100 & 18 & $18 \%$ \\
\hline
\end{tabular}

Table (2) shows the results of isolation of $L$. monocytogenes revealed the $\%$ of prevalence in minced meat, sausage, luncheon and basterma was $(4 \%, 0 \%, 0 \%$, $0 \%$ ) respectively.

Table (2): Number and percentage of L. monocytogenes of positive sample from meat products.

\begin{tabular}{cccc}
\hline $\begin{array}{c}\text { Types of } \\
\text { samples }\end{array}$ & $\begin{array}{c}\text { No. of } \\
\text { examined } \\
\text { samples }\end{array}$ & $\begin{array}{c}\text { Bacteriological } \\
\text { finding } \\
\text { No. of } \\
\text { positive } \\
\text { samples }\end{array}$ & $\%$ \\
\hline Minced meat & 25 & 1 & $4 \%$ \\
Sausage & 25 & 0 & $0 \%$ \\
Luncheon & 25 & 0 & $0 \%$ \\
Basterma & 25 & 0 & $0 \%$ \\
Total & 100 & 1 & $1 \%$ \\
\hline
\end{tabular}

Table (3) shows the results of isolation of E.coli revealed the prevalence in minced meat, sausage, luncheon and basterma was $(20 \%, 20 \%, 24 \%, 20 \%)$ respectively.

Table (3): Number and percentage of E. coliof positive sample from meat products

\begin{tabular}{cccc}
\hline $\begin{array}{c}\text { Types of } \\
\text { samples }\end{array}$ & $\begin{array}{c}\text { No. of } \\
\text { examined } \\
\text { samples }\end{array}$ & $\begin{array}{c}\text { Bacteriological } \\
\text { finding } \\
\text { No. of } \\
\text { positive } \\
\text { samples }\end{array}$ & $\%$ \\
\hline $\begin{array}{c}\text { Minced } \\
\text { meat }\end{array}$ & 25 & 5 & $20 \%$ \\
Sausage & 25 & 5 & $20 \%$ \\
Luncheon & 25 & 6 & $24 \%$ \\
Basterma & 25 & 5 & $20 \%$ \\
Total & 100 & 21 & $21 \%$ \\
\hline
\end{tabular}

\subsection{Results of Polymerase Chain Reaction (PCR)}

Figure (1) shows the optimization for validation of PCR on different gradient annealing temperatures from $56^{\circ} \mathrm{C}$ to $63{ }^{\circ} \mathrm{C}$ 
Detection of some foodborne pathogens in meat products by Polymerase Chain Reaction

Table (4): A detailed descriptions of the designed oligonucleotide primers used.

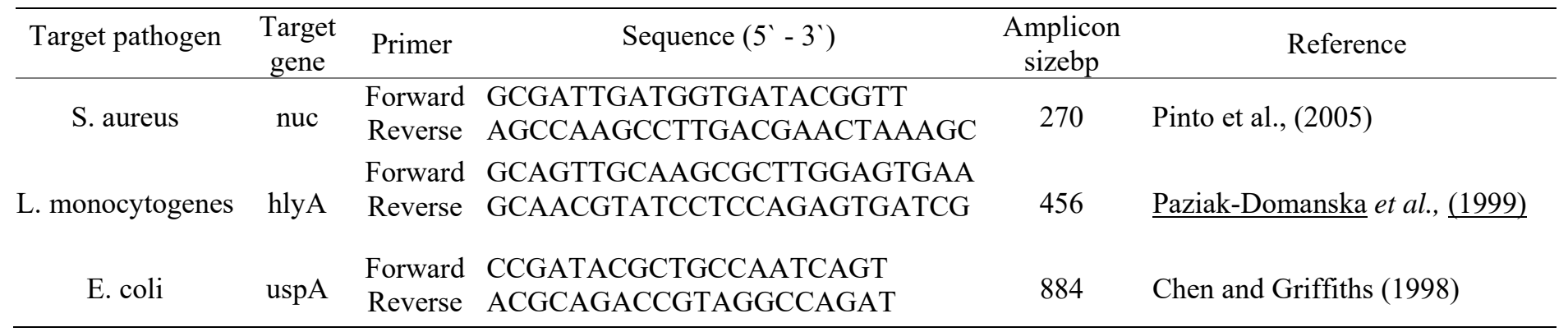

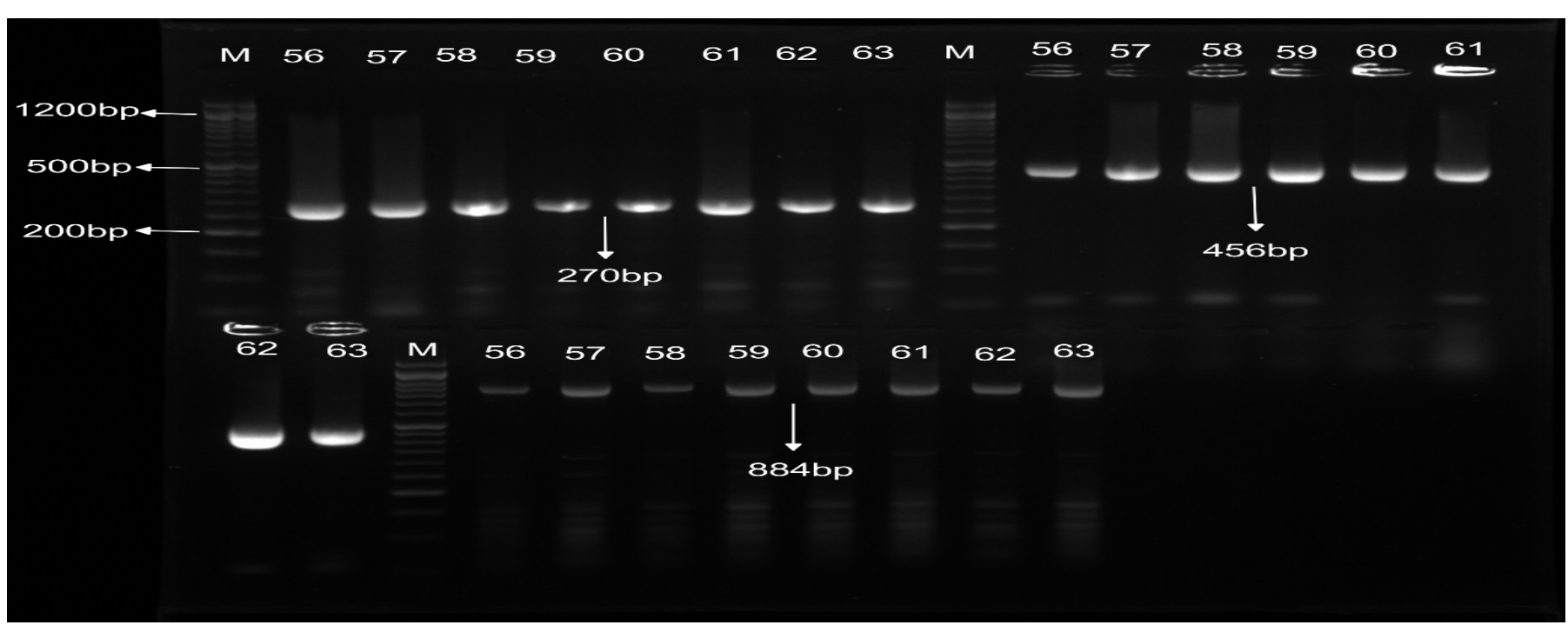

Figure (1): Uniplex gradient PCR using different annealing temperatures from $\left(56^{\circ}\right.$ to $\left.63^{\circ}\right)$.

M:marker (50bp).

$1^{\text {st }}$ group: annealing temperatures for staph. aureus from $56^{\circ}$ to $63^{\circ} \rightarrow(270 \mathrm{bp})$.

$2^{\text {nd }}$ group: annealing temperatures for L. monocytogenes from $56^{\circ}$ to $63^{\circ} \rightarrow(456 \mathrm{bp})$.

$3^{\text {rd }}$ group: annealing temperatures for E.coli from $56^{\circ}$ to $63^{\circ} \rightarrow(884 \mathrm{bp})$. 
on foodborne pathogens concerned in this study. The nuclease (nuc) gene of $S$. aureusamplify at specific band of $270 \mathrm{bp}$, hemolysin (hlyA) gene of $L$. monocytogenes amplify at specific band of $456 \mathrm{bp}$, and universal stress protein (uspA) gene of E. coli amplify at specific band of 884bp.

\section{DISCUSSION}

The foodborne pathogens are likely to cause serious public health problems, especially in developing countries where they lead to high level of morbidity and mortality rates. Quick, sensitive, specific and easy techniques for detection of the foodborne pathogens are needed for the effective implementation of food safety. Since its advent in the 1980s, polymerase chain reaction (PCR) has become indispensable tool in molecular diagnostics and can be very efficiently used in rapid detection of food-borne pathogens (Pinto et al., 2005).

In this study a total of 100 samples of meat products; minced meat and sausage (which represent raw meats), luncheon and basterma (which represent cooked meats) were examined bacteriologically to reveal the prevalence of foodborne pathogens as $S$. aureus, L. monocytogenes and E. coli and the percentage of prevalence was $(18 \%, 1 \%$, $21 \%$ ) respectively.

The obtained results of minced meat were nearly similar to (Vorster et al., 1994)they found S.aureusin $(23.4 \%)$ of minced beef in south Africa, and more than (Omar et al., 2009) who isolated S.aureusin a percentage of $(14.6 \%)$, and less than (Depourcq and Poucke, 1991)who determined the bacteriological quality of 52 samples of minced meat, S.aureuswere found in all samples which represents $(100 \%)$. In sausage results were nearly similar to (Soultos et al., 2003) who reported incidence of S.aureus in sausage (19.4\%) and less than (El-Khateib, 1997)who reported higher incidence of S.aureus in sausage (29\%). While On the other hand, our results of isolation from luncheon were nearly similar to those reported by(Fatin, 2004)who isolated S.aureusin (16\%), less than (Seham et al., 2013) who isolated S.aureusin $32 \%$. They mentioned that contamination may occur during the slicing and packaging of luncheon meat in supermarkets. The results of basterma examination were less than (Zakaria, 2007) who isolated S.aureusin (25\%).

The obtained results of minced meat were nearly similar to(El-gaml et al., 1998)who detected $L$. monocytogenes by $2(4 \%)$ of examined raw minced meat samples, and more than (Hua Wang et al., 1992) who failed to isolate $\mathrm{L}$. monocytogenes in China, and less than (Inoue et al., 2000)in percentage of 12.2 of examined minced meat samples. On the other hand, listeria. monocytogenes failed to be detected in the examined ready to eat meat products samples (luncheon and basterma), such result was similar to that obtained by (Gomez et al., 1999). On the contrary, (Furrer et al., 1991)who revealed the presence of L. monocytogenes in and (6\%) of examined luncheon samples and (Hanaa Kader et al., 2012)who revealed the presence of L. monocytogenes in $(26.6 \%)$ of examined basterma samples. However the low percentage may be due to addition spices, curing techniques and the temperature used during manufacture as well as good hygiene.

The obtained results of minced meat were nearly similar to(Ahmed, 1992) who examined 30 samples of minced meat where E. coli was isolated at $(17.5 \%)$, and more than (Blanco and Blanco, 1996)whorevealed that $3(5 \%)$ of 58 minced beef samples were positive, and less than (Shawki, 1990)who examined 25 minced meat samples where the percentage was (44\%)examined minced beef for detection of E. coli. In Sausage the obtained results were nearly similar to (Fathi et al., 1992) who examined sausage for E.coli where the incidence was $(20 \%)$, and more than (Ahmed, 1992) who examined 30 samples 
of sausage E. coli was isolated at (6.6\%), and less than (Mousa et al., 1993) isolated E.coli $(45 \%)$ of the examined sausage samples. While On the other hand, our results of isolation from luncheon were more than (Fawzy, 2004) who isolated E.coli from $(8 \%)$ of luncheon examined, and less than (Fathi et al., 1992)isolated E.coli $(41.67 \%)$ from luncheon. The results of basterma examination were nearly similar to (Fathi et al., 1992) who examined basterma for E.coli and the incidence was (19.37\%), and more than (Afaf, 2009) who examined 30 samples of basterma and found that E.coli incidence was (13.3\%).

On the other hand, PCR methods offer a sensitive and specific detection of pathogens. In the last 10 years, many authors have proposed the use of PCR for the detection of foodborne pathogens to replace the time consuming culture based classical techniques. They are rapid, easy to handle, sensitive and specific and therefore constitute very valuable tools for routine applications. The result of optimization for validation of PCR on different gradient annealing temperatures from $56^{\circ} \mathrm{C}$ to $63{ }^{\circ} \mathrm{C}$ on foodborne pathogens concerned in this study show great accordance with the results of (Chen et al., 2012);(Thapa et al., 2013)and(Kim et al., 2014) where they used gradient PCR on validation and detection of S. aureus, L. monocytogenes and E.coli but with different primers used in this study while(Guan et al., 2013) and (latha et al., 2014)used gradient PCR on validation and detection of $S$. aureus and $L$. monocytogenes with same primers used in this study.On the other hand, (Kupradit et al., 2013)used gradient PCR on validation and detection of $L$. monocytogenes and $E$. coli with only the (uspA) gene of E. coli with the prfA gene of L. monocytogenes.

\section{REFERENCES}

Afaf, M.A. 2009. Different serotypes of E.coli and Salmonellae in some meat products and their behavior during different heat treatments and cold storage. Ph.D Thesis, Fac. Vet. Med., Cairo Univ.

Ahmed, M.N. 1992. Incidence and occurrence of salmonella and E.coli organisms in packed meat products in Assiut. M.V.Sc. thesis: Fac. of Vet. Med., Assiut University.

Blanco, J., Blanco, M. 1996. Detection of Enterohaeamorrhagic Escherichia coli $\mathrm{O} 157: \mathrm{H7}$ in minced beef using immunomagnetic separation. Journal of Applied Microbiology.12(3):38594.

Chen, J., Griffiths, M.W. 1998. PCR differentiation of Escherichia coli from other Gram-negative bacteria using primers derived from the nucleotide sequences flanking the gene encoding the universal stress protein. Lett. Appl. Microbiol. 27:369-371.

Chen, J., Tang, J., Liu, J., Cai, Z., Bai, X. 2012. Development and evaluation of a multiplex PCR for simultaneous detection of five foodborne pathogens. Journal of Applied Microbiology.112: 823-830.

Depourcq, G., Poucke, L.V. 1991. Evaluation of the microbiological quality of minced meat. Lab. For pharmaceutical microbial. Hygiene Univ. of Gent. Harelbekestraat 72, B. 9000 Ghent, Belgium.

El-gaml, A.M., EL-Gmiey, S.R., Ahmed, A.M. 1998. Isolation of Listeria spp. from raw chicken and locally minced meat in Mansoura City, Egypt. Zag. Vet. J. 26 (1): 48 - 53.

El-Khateib, T. 1997. Microbiological status of Egyptian salted meatand fresh sausage. Journal of Food Safety, 17(3):141-150.

Fathi, S.M., Rashwan, M.R., El-said, S.I. 1992. Determination of coliforms and E.coli in some meat products using most probable number technique. Assuit Vet., Med. J.24 (55): 180

Fatin, S.H. 2004. Bacterial Hazards Associated with Consumption of 
Some Meat Products. Benha Vet. Med. J., 15(2): 41-54.

Fawzy, A.A. 2004. Studies on cooked meat and chicken products, Ph.D. Fac. VET. Med. Zagazig Univ. Benha Branch.

Furrer, B., Candrian, U., Hocfelein, Ch., Leuethy, J. 1991. Detection and identification of Listeria monocytogenes in cooked sausage products and in milk in vitro amplication of haemolysin gene fraginents. J. Appl. Bacteriol., 70: $372-379$.

Gomez, Gampillo, J.L., Dominguez Fernandez, M. C., ZumalCarreguiRodriguez, J.M. 1999. Incidence of Listeria monocytogenes and Escherichia coli O157:H7 in meat and meat products markated at Castilla and Leon. Alimenntaria. 36 303: $71-75$.

Guan, Z. P., Jiang, Y., Gao, F., Zhang, L., Zhou, G. H., Guan, Z. J. 2013. Rapid and simultaneous analysis of five foodborne pathogenic bacteria using multiplex PCR. European Food Research and Technology, 237(4): 627-637.

Hanaa, A., Ahmed, Amal, A.M., Gihan, M.O. 2012. Molecular detection of pathogenic genes of Listeria monocytogenes as food poisoning micro-organism isolated from ready to eat meals in Port-Said city markets.Assuit vet .Med.J., 132(58):51-67.

Henegariu, O., Heerema, N. A., Dlouhy, S. R., Vance, G, H., Vogt, P. H. 1997. Multiplex PCR critical parameters and step-by-step protocol. Bio Techniques 23:504-511.

Huang, Xuehui, Feng, Qi Qian, Qian Zhao, Qiang, Wang, Lu Wang, Ahong, Guan, Jianping, Fan, Danlin, Weng, Qijun, Huang, Tao Dong, Guojun, Sang, Tao, Han, Bin. 2009. HighThroughput Genotyping by WholeGenome Resequencing. Genome research 19: 1068-76.
Hua Wang, G., Ting Yan, K.E., Ming Feng, X., Ming Chen, Su.Kui, Al-Ping., Kokubo, Y. 1992. Isolation and identification of Listeria monocytogenes from retail meats in Beijing. J. of Food Prot., 55 (1): 560 58.

Inoue, S., Nakama, A.A., AraiyKokubo, Y., Maruyama, T., Saito, A., Yoshida, T., Terao, M., Yamamoto, S., Kumagai, S. 2000. Prevalence and contamination levels of Listeria monocytogenes in retail foods in Japan. Int. Food Microbiol., 25 (1): $73-77$.

International Commission on the Microbiological Specification for food. "ICMSF" 1978 Microorganism in Foods, Their Significance and Method of Enumeration $.2^{\text {nd }} \mathrm{Ed}$ Univ.of Toronto Press. Toronto Canada.

ISO 11290-1 1996. Microbiology of food and animal feeding stuffs-horizontal method for the detection and enumeration of Listeria monocytogenes. Part 1: detection method. Geneva: International Organization for Standardization.

Jasson, V., Jacxsens, L., Luning, P., Rajkovic, A., Uyttendaele, M. 2010. Review. Alternative microbial methods: An overview and selection criteria. Food Microbiol., 27:710 730.

Judge, M. D. 1990. Principle of meat sciences.Kendall Hunt Publishing Company, Dubuque, Iowa, USA.

Kim, J., Rhim, S., Kim, K., Paik, H., Lee, J. 2014. Simultaneous Detection of Listeria monocytogenes , Escherichia coli O157: H7 , Bacillus cereus, Salmonella spp ., and Staphylococcus aureus in Lowfatted Milk by Multiplex PCR.Korean J. Food Sci. An 34(5): 715-716.

Koneman , E.W., Allen, S. D., Janda, W. M., Schreckenberger,P. C., Winn, M.D. 1996. Introduction to 
Diagnostic Microbiology $6^{\text {th }}$ ed., Lippincott Company, Philadelphia, USA.

Kupradit, C., Rodtong, S., Ketudat-cairns, M. 2013. Novel Multiplex PCR to Specifically Detect Bacterial Foodborne Pathogens, 20(1), 7382.

Latha, C.C.A., Sunil, B.V.A., Jolly, D. 2014. Multiplex PCR assay for the simultaneous detection of four common food pathogens in meat. Journal of Foodborne and Zoonotic Diseases 2(3): 45-49.

Omar, H.S., Ikbal, A.A., Entesar. R.A. 2009. Extraction of Staphylococcus aureus toxin from minced meat in Mosul City. The Iraq J. for Vet Med 23 (1): 27-32.

Paziak-Domanska, B., Bogulawska, E., Wiekowska-Szakiel, M., Kotlowski, R., Rozalska, B., Chmiela, M., Kur, J. 1999. Evaluation of the API test, phosphatidylinositol-specific phospholipase $\mathrm{C}$ activity and PCR method in identification of Listeria monocytogenesin meat foods. FEMS Microbiol. Lett171: 209214.

Pinto, B., Chenoll, E., Aznar, R. 2005. Identification and typing of foodborne Staphylococcus aureus by PCR-based techniques SystApplMicrobiol, 28: 340-352.

Quinn, P.J., Markey, B.K., Carter, M.E., Donnelly, W.J.C., Leonard, F.C., Maguire, D. 2002. Veterinary Microbiology and Microbial diseases. Published Blackwell science $1^{\text {st }} \mathrm{d}$.
Seham, A.I., Amal, A.S., El-diasty, E.M. 2013. Microbiological Quality of Some Meat Products in Local Markets with Special Reference to Mycotoxins. Global Veterinaria 10 (5): 577-584.

Shawki, E.M. 1990. Escherichia coli in meat products with special reference to enteropathogenic strains. M.V.Sc. Thesis (meat hygiene), Fac. Vet. Med., Cairo University.

Soultos, N., Abrahim, A., Abrosiadis, I. 2003. Incidence of some food born bacterial pathogens in traditional sausages produced in northen Greece. Archiv. Furer. Lebensmittel. Hygiene, 54(3):5557.

Thapa, S.P., Han, A.R., Cho, J.M., Hur, J.H. 2013. Multiplex PCR and DNA array for the detection of Bacillus cereus, Staphylococcus aureus, Listeria monocytogenes, Escherichia coli O157:H7, and Salmonella spp. targeting virulencerelated genes. Annals of Microbiology, 63(2): 725-731.

Vorster, S.M., Greebe, R.P., Nortje, G.L. 1994. Incidence of Staphylococcus aureus and Escherichia coli in ground beef, broilers and processed meat in Pretoria, South Africa. Journal of Food Prot., 57(4):305310.

Zakaria, H. H. 2007. Studies on food poisoning microorganisms in some meat products. Master Thesis (Meat Hygiene \& control). Menoufia University Faculty of Vet. Med., Sadat branch. 